\title{
Penyaluran Kredit Bank Umum di Indonesia Ditinjau dari Risiko Kredit dengan Profitabilitas Sebagai Mediasi
}

\author{
Raden Bagus Faizal Irany Sidharta, Abdurrahman, Isra Dewi Kuntary Ibrahim \\ Universitas Bumigora \\ ronyfaiza193@gmail.com, abdurrahman@universitasbumigora.ac.id \\ israibrahim@universitasbumigora.ac.id
}

\begin{abstract}
Abstrak
Penelitian ini bertujuan untuk menganalisis pengaruh risiko kredit terhadap profitabilitas, menganalisis pengaruh risiko kredit terhadap alokasi kredit, menganalisis pengaruh profitabilitas terhadap alokasi kredit pada perbankan komersial di Indonesia. Metode analisis yang digunakan adalah analisis jalur dengan smart PLS. Hasil empiris kami menunjukkan bahwa risiko kredit berpengaruh negatif dan signifikan terhadap profitabilitas, risiko kredit tidak berpengaruh signifikan terhadap alokasi kredit, profitabilitas berpengaruh positif signifikan terhadap alokasi kredit dan juga risiko kredit berpengaruh negatif terhadap alokasi kredit melalui profitabilitas pada perbankan komersial di Indonesia
\end{abstract}

Kata kunci : risiko kredit, profitabilitas, alokasi kredit

\begin{abstract}
This research was aimed at finding to analyze the effect of credit risk on profitability, to analyze the effect of credit risk on credit allocation, to analyze the effect of profitability on credit allocation at commercial banking in Indonesia. The method of analyze was path analysis by smart PLS. Our empirical results showed that credit risk had a negative and significant effect to profitability, credit risk did not have significant effect to credit allocation, profitability had a positive significant effect to credit allocation and also credit risk had a negative effect on credit allocation through profitability at commercial banking in Indonesia
\end{abstract}

Keywords : credit risk, profitability, credit allocation 


\section{Pendahuluan}

Bank memiliki peran penting dan sangat vital bagi perekonomian suatu negara. Sebagai agen pembangunan, bank memiliki tanggung jawab untuk ikut menaikkan taraf hidup masyarkat dan mengurangi angka kemiskinan. Bank memiliki peran dan fungsi sebagai lembaga intermediasi yang secara langsung dapat membantu masyarakat. Dalam konteks ini, bank menerima simpanan uang dari masyarakat dan kemudian menyalurkan kembali dalam bentuk kredit (Amelia \& Murtiasih, 2017). Menurut Mukhlis (2011) kegiatan penyaluran kredit ini sangat mengandung risiko yang dapat mempengaruhi kesehatan dan kelangsungan usaha bank. Likuiditas keuangan, solvabilitas dan profitabilitas keuangan bank umumnya dipengaruhi oleh keberhasilan bank dalam mengelola kredit yang disalurkan.

Kredit sendiri, merupakan salah satu pendapatan utama bank, karena kredit memberikan keuntungan yang cukup besar dibandingkan dengan usaha bank lainnya seperti biaya jasa penyimpanan dana tabungan, biaya jasa pengiriman antar bank dan sebagainya (Pratiwi \& Hindasah, 2014). Dalam kurun waktu 5 tahun terakhir, dari tahun 2012 hingga 2016 penyaluran kredit perbankan di Indonesia mengalami kenaikan. Pada tahun 2012 penyaluran kredit perbankan di Indonesia sebesar 4.172.672 miliar lalu pada tahun 2013 menjadi sebesar 4.823.303 miliar, pada tahun 2014 sebesar 5.468.910 miliar, lalu pada tahun 2015 penyaluran kredit bank umum di Indonesia sebesar 5.952.279 miliar dan pada tahun 2016 sebesar 6.507.903 miliar.

Meskipun penyaluran kredit bank umum di Indonesia mengalami kenaikan tiap tahunnya namun kenaikan tersebut tidak memenuhi ekspektasi Bank Indonesia selaku otoritas moneter untuk mampu menggenjot pertumbuhan ekonomi Indonesia (BI, 2016). Berdasarkan Laporan Perekonomian Indonesia Tahun 2016, salah satu penyebab penyaluran kredit bank umum di Indonesia tidak mampu menggenjot pertumbuhan ekonomi dikarenakan terjadinya peningkatan kredit macet atau risiko kredit yang dialami oleh bank-bank umum di Indonesia.

Menurut Mukhlis (2011) kredit macet atau kredit bermasalah adalah kondisi ketika debitur tidak mampu memenuhi kewajibannya sesuai dengan kesepakatan semula ketika kredit diberikan. Tentu kondisi ini akan mengakibatkan bank mengalami kerugian. Semakin besar kredit macet yang dihadapi oleh bank akan semakin meningkatkan rasio NPL atau non performing loan bank tersebut. Ketika NPL dari bank meningkat maka hal ini akan menyebabkan dana yang disalurkan melalui kredit juga akan semakin berkurang karena bank harus membentuk cadangan penghapusan yang lebih besar (Amelia \& Murtiasih, 2017).

Selain itu juga, apabila rasio NPL suatu bank semakin tinggi maka hal ini mengindikasikan bahwa kualitas kredit yang diberikan oleh bank buruk menyebabkan jumlah kredit macet atau kredit bermasalah semakin besar, sehingga hal ini mempegaruhi laba yang diperoleh bank atau dengan kata lain, bank dengan tingkat pemberian kredit yang besar tanpa diimbangi dengan kemampuan dalam menjaga kualitas kreditnya akan berdampak kepada profitabilitas bank yang tercermin dengan menurunnya return on assets atau ROA (Anggreni \& Suardhika, 2014).

Profitabilitas pada perbankan yang diproksikan dengan ROA banyak digunakan untuk mengukur kesuksesan dan kinerja bank (Widokartiko, Achsani, \& Beik, 2016). ROA digunakan untuk mengukur tingkat kemampuan perusahaan dalam menghasilkan kentungan melalui penggunaan aktiva yang dimilikinya. Semakin besar ROA menunjukkan kinerja keuangan yang semakin baik, karena tingkat pengembalian atau return semakin besar (Septiani \& Lestari, 2016). Profitabilitas merupakan tujuan dari setiap perusahaan bisnis didirikan. Begitupun dengan bisnis bank. Profitabilitas bank menjadi penting karena merupakan salah satu ukuran dari 
kesehatan bank itu sendiri. Menurut Li and Zou (2014) kesehatan bank sangat bergantung dari kondisi profitabilitas bank itu sendiri. Profitabilitas merupakan parameter yang dapat digunakan untuk menunjukkan seberapa jauh manajemen mampu membawa usaha bank tersebut bertahan di tengah kompetisi bank yang semakin berat saat ini. Profitabilitas suatu bank sangat ditentukan oleh tingkat risiko kredit.

Profitabilitas juga dapat menjadi suatu ukuran penyaluran kredit dari bank itu sendiri. Ketika profitabilitas bank meningkat maka hal ini menunjukkan bahwa posisi bank berada dalam keadaan yang baik. Dalam arti, bank mampu menghasilkan keuntungan bagi para pemegang saham. Maka ketika profitabilitas dari bank tersebut meningkat, hal ini akan memudahkan bank untuk menyalurkan kembali kepada masyarakat (Pratiwi \& Hindasah, 2014). Hal ini mengindikasikan bahwa profitabilitas bank dapat menjadi suatu jembatan hubungan antara risiko kredit dengan jumlah penyaluran kredit perbankan. Karena profitabilitas bank merupakan salah satu elemen kunci untuk mengukur kemampuan bank dalam menjalankan operasi sehari-harinya. Hal ini didukung oleh hasil penelitian yang dilakukan oleh Yuliana (2014) yang menemukan bahwa risiko kredit berpengaruh terhadap penyaluran kredit bank umum di Indonesia, risiko kredit berpengaruh terhadap profitabilitas bank umum di Indonesia dan profitabilitas berpengaruh terhadap penyaluran kredit bank umum di Indonesia.

Hasil penelitian ini berbeda dengan penelitian yang dilakukan oleh Putri and Suwarti (2013) yang menemukan risiko kredit tidak berpengaruh terhadap penyaluran kredit dan profitabilitas tidak berpengaruh terhadap penyaluran kredit. Sementara itu, penelitian yang dilakukan oleh Mahardian (2008) menemukan bahwa risiko kredit tidak berpengaruh terhadap profitabilitas bank umum di Indonesia. Hasil yang berbeda ditemukan dalam penelitian yang dilakukan oleh Puspitasari (2009) menemukan bahwa risiko kredit berpengaruh terhadap profitabilitas dari bank umum di Indonesia. Penelitian ini menggunakan bank umum komersial, karena memiliki peranan yang sangat penting dalam menggerakan roda perekonomian nasional. Lebih dari 95 persen dana pihak ketiga yang disalurkan dalam bentuk kredit perbankan nasional berasal dari bank umum (Pratama, 2010). Oleh karena itu, tujuan penelitian ini adalah untuk menganalisis pengaruh risiko kredit terhadap profitabilitas bank umum di Indonesia, untuk menganalisis pengaruh risiko kredit terhadap penyaluran kredit bank umum di Indonesia, untuk menganalisis pengaruh profitabilitas terhadap penyaluran kredit bank umum di Indonesia.

\section{Hipotesis}

Berdasarkan teori dan beberapa penelitian terdahulu, maka hipotesis dapat dirumuskan sebagai berikut:

$\mathrm{H}_{1}$ : Risiko kredit berpengaruh terhadap profitabilitas bank umum di Indonesia

$\mathrm{H}_{2}$ : Risiko kredit berpengaruh terhadap penyaluran kredit bank umum di Indonesia

$\mathrm{H}_{3}$ : Profitabilitas berpengaruh terhadap penyaluran kredit bank umum di Indonesia

\section{Metode}

Populasi dalam penelitian ini adalah seluruh bank umum yang terdaftar di Bursa Efek Indonesia. Dari populasi tersebut dipilih sampel dengan teknik purposive sampling. Adapun kriteria sampel yang digunakan adalah sebagai berikut: 1. Bank Umum yang terdaftar di Bursa Efek Indonesia, 2. Bank umum yang telah terdaftar di Bursa Efek Indonesia sejak tahun 2012 
atau sebelumnya, 3. Bank umum yang masih beroperasi antara tahun 2012 hingga 2016, 4. Bank umum yang memiliki laporan keuangan dan laporan tahunan secara berturut-turut dan memiliki data yang lengkap pada periode 2012-2016. Dengan kriteria yang telah ditetapkan, maka sampel dalam penelitian ini berjumlah 27 bank umum di Indonesia, sebagai berikut:

Tabel 1. Kode Emiten yang Menjadi Sampel

\begin{tabular}{ll}
\hline BACA & BSWD \\
\hline BBCA & BTPN \\
BBKP & BVIC \\
BBNI & INPC \\
BBNP & MAYA \\
BBTN & MCOR \\
BBYB & MEGA \\
BCIC & NISP \\
BDMN & PNBN \\
BEKS & SDRA \\
BJBR & BKSW \\
BJTM & BNGA \\
BNII & BNLI \\
BSIM & \\
\hline
\end{tabular}

\section{Sumber : Data Diolah}

Data yang digunakan dalam penelitian ini adalah data sekunder yang diperoleh dari Bursa Efek Indonesia yang terdapat publikasi baik laporan keuangan maupun laporan tahunan perbankan melalui website www.idx.co.id. Sehubungan dengan tujuan penelitian ini maka terdapat tiga indikator yang digunakan dalam penelitian ini yaitu NPL, ROA dan jumlah penyaluran kredit. NPL atau non performing loan adalah indikator dalam mengukur kemampuan manajemen bank umum di Indonesia dalam mengelola kredit bermasalah. NPL dihitung berdasarkan perbandingan antara jumlah kredit yang bermasalah dibandingkan dengan total kredit. Penghitungan NPL dapat diformulasikan sebagai berikut

$\mathrm{NPL}=\frac{\text { KREDIT BERMASALAH }}{\text { TOTAL KREDIT }} \times 100 \%$

Keterangan:

NPL : Non Performing Loan

Kredit Bermasalah :kredit yang tergolong kurang lancar dan sebagainya

Total Kredit : Jumlah total aktiva

Kemudian, ROA atau return on assets menunjukkan kemampuan bank umum di Indonesia dalam menghasilkan laba dengan rumus sebagai berikut

$\mathrm{ROA}=\frac{\mathrm{EBIT}}{\text { Total Aset }} \mathrm{X} 100 \%$

Keterangan:

ROA :Return on Assets

EBIT :Earning Before Interest and Taxes

Total Aset :Jumlah total aktiva 
Kemudian, penyaluran kredit merupakan jumlah penyaluran kredit masing-masing bank umum di Indonesia pada periode 2012 hingga 2016 yang terdapat dalam laporan keuangan dan laporan tahunan. Sesuai dengan tujuan penelitian ini maka metode analisis yang digunakan adalah analisa jalur dengan bantuan software smartPLS.

\section{Hasil}

\section{Evaluasi Model Struktural}

Penilaian terhadap model structural atau inner model dilakukan untuk melihat hubungan antar konstruk, nilai signifikansi dan R-Square model penelitian.

Tabel 2. Nilai R-Square

\begin{tabular}{|c|c|c|c|c|}
\hline No & $\begin{array}{c}\text { Hubungan Antar } \\
\text { Variabel }\end{array}$ & Koefisien Jalur & t-statistik & Kesimpulan \\
\hline 1. & $\mathrm{NPL}(\mathrm{X}) \rightarrow \mathrm{ROA}(\mathrm{Z})$ & $-0,516$ & 5,950 & Signifikan \\
\hline 2. & NPL (X) $\rightarrow$ KREDIT (Y) & $-0,181$ & 1,525 & Tidak Signifikan \\
\hline \multirow[t]{4}{*}{3.} & ROA $(\mathrm{Z}) \rightarrow \operatorname{KREDIT}(\mathrm{Y})$ & 0,155 & 1,858 & Signifikan \\
\hline & $\overline{\text { Variabel }}$ & $\overline{\text { R-Square }}$ & & \\
\hline & $\overline{R O A}$ & 0,085 & & \\
\hline & KREDIT & 0,265 & & \\
\hline
\end{tabular}

Sumber : Data diolah

Nilai Q-Square dapat diperoleh melalui rumus :

$$
\begin{aligned}
& \mathrm{Q}^{2}=1-\left(1-\mathrm{R}_{2}^{2}\right)\left(1-\mathrm{Rp}^{2}\right) \\
& \mathrm{Q}^{2}=1-\left(1-0,085^{2}\right)\left(1-0,265^{2}\right) \\
& \mathrm{Q}^{2}=1-(0,993)(0,070) \\
& \mathrm{Q}^{2}=1-0,069 \\
& \mathrm{Q}=\sqrt{0,931} \\
& \mathrm{Q}=0,964
\end{aligned}
$$

Nilai Q-Square diketahui sebesar 0,964 atau sama dengan 96,4\% artinya adalah keragaman data dapat dijelaskan oleh model penelitian ini sebesar 96,4 persen atau dengan kata lain informasi yang terkandung dalam data sebesar 96,4 persen dapat dijelaskan oleh model penelitian ini sedangkan sisanya 3,6 persen dijelaskan oleh variabel lain yang tidak terdapat dalam penelitian ini seperti capital adequacy ratio, net interest margin, inflasi, dan BI rate.

\section{Pengujian Koefisien Jalur}


Hasil pengujian hubungan antar variabel penelitian dapat dilihat dari nilai koefisien jalur dan titik kritis t-statistic yang signifikan pada $\alpha=0,05$.

\section{a. Pengujian Hipotesis 1 : Pengaruh Risiko Kredit Terhadap Profitabilitas}

Hipotesis 1 menyatakan bahwa risiko kredit berpengaruh signifikan terhadap profitabilitas. Hasil uji terhadap koefisien parameter antara risiko kredit terhadap profitabilitas menunjukkan adanya pengaruh dengan tanda negatif dengan nilai koefisien -0,516 dengan nilai $t$ statistic sebesar 5,950 > 1,680 menunjukkan pengaruhnya signifikan. Ha diterima.

\section{b. Pengujian Hipotesis 2 : Pengaruh Risiko Kredit Terhadap Penyaluran Kredit}

Hipotesis 2 menyatakan bahwa Risiko kredit berpengaruh terhadap penyaluran kredit bank umum di Indonesia ditolak. Hasil uji terhadap koefisien parameter antara risiko kredit terhadap penyaluran kredit menunjukkan tidak adanya pengaruh dan negatif dengan nilai koefisien -0,181 dengan nilai t statistic sebesar 1,525 < 1,680 menunjukkan pengaruhnya tidak signifikan. Ha ditolak

\section{c. Pengujian Hipotesis 3 : Pengaruh Profitabilitas Terhadap Penyaluran Kredit}

Hipotesis 3 menyatakan bahwa profitabilitas berpengaruh positif signifikan terhadap penyaluran kredit. Hasil uji terhadap koefisien parameter antara profitabilitas terhadap penyaluran kredit menunjukkan adanya pengaruh positif dengan nilai koefisien 0,158 dengan nilai t statistik sebesar 1,858>1,680 menunjukkan pengaruhnya signifikan. Ha diterima

\section{Mediasi Variabel/Pengaruh Tidak Langsung (Indirect Effect)}

Besarnya pengaruh tidak langsung variabel risiko kredit terhadap penyaluran kredit dengan mediasi profitabiltias diperoleh melalui hasil perkalian koefisien jalur (beta) antara pengaruh

\begin{tabular}{lcc}
\hline \multicolumn{1}{c}{ Pengaruh Variabel } & $\begin{array}{c}\text { Formula } \\
\text { Perhitungan }\end{array}$ & Hasil \\
\hline Rangkuman Pengaruh Langsung (Direct Effect) & & \\
NPL $(\mathbf{X}) \rightarrow$ ROA (Z) & - & $-0,516$ \\
NPL $(\mathbf{X}) \rightarrow$ KREDIT (Y) & - & $-0,181$ \\
ROA $(\mathbf{Z}) \rightarrow$ KREDIT (Y) & - & 0,158 \\
Rangkuman Pengaruh Tidak Langsung (Indirect Effect) & $(-0,516 \times 0,155)$ & $-0,079$ \\
NPL $(\mathbf{X}) \rightarrow$ ROA $(\mathbf{Z}) \rightarrow$ KREDIT (Y)
\end{tabular}

langsung risiko kredit terhadap profitabilitas dengan pengaruh langsung profitabilitas terhadap penyaluran kredit seperti ditunjukkan pada tabel 3

\section{Pembahasan}

\section{Pengaruh Risiko Kredit Terhadap Profitabilitas}

Pada tabel 3, menunjukkan nilai koefisien dari variabel NPL sebesar -0,516. Artinya pengaruh risiko kredit yang di proksikan oleh NPL terhadap profitabilitas yang diproksikan oleh ROA arahnya adalah negatif dengan nilai t-statistik sebesar 5,950 lebih besar daripada 1,680 dimana nilai t-table untuk hipotesis satu ekor (one-tailed) dengan tingkat keyakinan 95 persen $(\alpha=0,05)$ adalah 1,680. Ketika t-statistik lebih besar dari 1,680 maka Ha diterima. Hal ini 
menunjukkan bahwa semakin tinggi risiko kredit yang dihadapi oleh bank umum di Indonesia akan menurunkan profitabilitas dari bank umum tersebut. Hasil penelitian ini sejalan dengan hasil penelitian yang dilakukan oleh (Yuliana (2014)) bahwa risiko kredit berpengaruh negatif dan signifikan terhadap profitabilitas bank umum di Indonesia. Risiko kredit terjadi ketika bank memberikan pinjaman kepada nasabah sesuai dengan jangka waktu yang telah disepakati, kemudian nasabah tersebut tidak mampu untuk mengembalikan pinjaman yang telah diterimanya pada saat jatuh tempo beserta bunganya, hal itu bisa disebabkan karena kesengajaan maupun tanpa tidak sengaja. Menurut Herlina et al (2016) risiko kredit merupakan faktor yang sangat mempengaruhi profitabilitas dari bank. Timbulnya kredit bermasalah mengakibatkan hilangnya kesempatan untuk memperoleh pendapatan dari kredit yang diberikan sehingga mengurangi perolehan laba dan mengakibatkan return on assets menurun. Dalam kurun waktu 2013 hingga 2016 angka risiko kredit bank umum di Indonesia menunjukan peningkatan yang cukup tajam, Non performing Loan (NPL) pada tahun 2013 menunjukkan angka 1,77 persen, lalu pada tahun 2014 meningkat menjadi 2,04 persen, pada tahun 2015 meningkat kembali menjadi 2,49 persen dan pada tahun 2016 meningkat cukup tajam menjadi 2,93 persen. Trend peningkatan NPL pada bank umum di Indonesia perlu dicermati secara serius dan mendalam karena hal ini sangat berdampak kepada profitabilitas bank secara keseluruhan.

Hal ini mengindikasikan agar bank benar-benar selektif dalam menyalurkan kreditnya ke masyarakat. Penguatan akan prinsip-prinsip penilaian bank dalam penyaluran kredit agar tidak terjadi kredit bermasalah sangat dibutuhkan. Menurut Saroinsong (2014) kriteria penilaian yang harus dilakukan bank meliputi watak (character), jaminan (collateral), modal (capital), kemampuan (capacity), kondisi ekonomi (condition of economy) dan kompetensi (competency). Selain itu, bank harus memperhatikan dengan teliti terkait dengan personality (tingkah laku), party (penggolongan calon debitur agar pengelolaan dari calon nasabah tersebut tepat sasaran, purpose (tujuan calon nasabah mengambil kredit), prospect (prospek usaha calon nasabah), payment (ukuran bagaimana calon nasabah mampu mengembalikan kredit yang telah dipinjamnya, profitability (kemampuan calon nasabah dalam memperoleh keuntungan dari usahanya) dan protection (hubungan antara calon nasabah dan bank yang dilandasi rasa percaya). Maka bank harus memperkuat 6C dan 7P tersebut agar dapat terhindar dari kredit bermasalah yang dapat menurunkan profitabilitas bank itu sendiri.

\section{Pengaruh Risiko Kredit Terhadap Penyaluran Kredit}

Pada tabel 3, menunjukkan nilai koefisien dari variabel NPL sebesar -0,181. Artinya pengaruh risiko kredit yang di proksikan oleh NPL terhadap profitabilitas yang diproksikan oleh ROA arahnya adalah negatif dengan nilai t-statistik sebesar 1,525 lebih kecil daripada 1,680 dimana nilai t-table untuk hipotesis satu ekor (one-tailed) dengan tingkat keyakinan 95 persen $(\alpha=0,05)$ adalah 1,680. Ketika t-statistik lebih kecil dari 1,680 maka Ha ditolak. Berdasarkan hasil penelitian ini maka risiko kredit terhadap penyaluran kredit tidak berpengaruh. Hasil penelitian ini sesuai dengan hasil penelitian yang dilakukan oleh Putri and Suwarti (2013) yang menemukan risiko kredit tidak berpengaruh terhadap penyaluran kredit. Hal ini mengindikasikan bahwa meskipun tingkat risiko kredit yang mengalami peningkatan dalam kurun waktu 5 tahun terakhir tidak berefek kepada jumlah penyaluran kredit kepada masyarakat. Hal ini dikarenakan ketika tingkat risiko kredit tersebut meningkat, maka bank meningkatkan capital adequacy ratio atau CAR.

Menurut Haryanto and Widyarti (2017) CAR merupakan tingkat kecukupan modal yang dimiliki oleh bank. CAR salah satu indikator kesehatan bank yang dapat digunakan untuk 
meredam shock atau risiko terhadap kegiatan operasionalnya. Semakin tinggi CAR maka tingkat ketahanan bank terhadap risikonya akan semakin baik. Salah satunya adalah untuk mengantisipasi adanya kenaikan dari kredit bermasalah yang dihadapi. Dalam kurun waktu 2012 hingga 2016 bank umum di Indonesia memiliki kondisi CAR yang sangat baik dan berada jauh di atas batas minimum yang ditetapkan oleh Bank Indonesia sebesar 8 persen. Sehingga CAR tersebut dapat membantu meng-cover risiko kredit yang diakibatkan oleh kredit bermasalah. Sehingga meskipun tingkat risiko kredit bermasalah pada bank umum di Indonesia meningkat namun tidak mempengaruhi jumlah penyaluran kredit kepada masyarakat.

\section{Pengaruh Profitabilitas Terhadap Penyaluran Kredit}

Pada tabel 3, menunjukkan nilai koefisien dari variabel ROA sebesar 0,155. Artinya pengaruh profitabilitas yang di proksikan oleh ROA terhadap penyaluran kredit arahnya adalah positif dengan nilai t-statistik sebesar 1,858 lebih besar daripada 1,680 dimana nilai t-table untuk hipotesis satu ekor (one-tailed) dengan tingkat keyakinan 95 persen $(\alpha=0,05)$ adalah 1,680. Ketika t-statistik lebih besar dari 1,680 maka Ha diterima. Hal ini menunjukkan bahwa semakin tinggi profitabilitas bank umum di Indonesia akan meningkatkan penyaluran kredit dari bank umum tersebut.

Hal ini menunjukkan bahwa dalam kurun waktu 2012 hingga 2016 penyaluran kredit bank umum di Indonesia ditopang oleh kemampuan bank dalam menunjukkan kinerjanya memperoleh laba. Hal ini sesuai dengan pernyataan Pratiwi and Hindasah (2014) bahwa ketika bank umum memiliki profitabilitas yang semakin tinggi maka bank akan lebih mudah untuk menyalurkan dananya kepada masyarakat. Menurut Satria dan Subegti (2010) tingkat profit atau keuntungan yang diperoleh oleh bank umum mampu memberikan motivasi tersendiri bagi pihak bank umum untuk meningkatkan profit atau kuntungan dengan cara menyalurkan kredit untuk menghasilkan keuntungan maksimal.

\section{Pengaruh Risiko Kredit Terhadap Penyaluran Kredit Melalui Profitabilitas}

Dalam penelitian ini, terdapat pengaruh tidak langsung antara variabel risiko kredit terhadap penyaluran kredit melalui profitabilitas dengan nilai koefisien sebesar -0,079. Dari perhitungan tersebut, memberi arti bahwa terdapat pengaruh tidak langsung antara variabel risiko kredit dengan penyaluran kredit melalui variabel profitabilitas. Perbandingan pengaruh tidak langsung risiko kredit terhadap penyaluran kredit melalui profitabilitas dengan pengaruh langsungnya antara risiko kredit terhadap penyaluran kredit diperoleh hasil - 0,079<-0,181. Meskipun, hasil langsung dari risiko kredit terhadap penyaluran kredit melalui profitabilitas lebih kecil daripada pengaruh langsungnya antara risiko kredit terhadap penyaluran kredit, tetapi risiko kredit tidak berpengaruh terhadap penyaluran kredit secara langsung. Sehingga bisa dinyatakan bahwa profitabilitas berfungsi sebagai full mediation dalam pengaruh risiko kredit terhadap penyaluran kredit bank umum di Indonesia dan berpengaruh negatif.

Hasil penelitian ini menunjukkan bahwa risiko kredit berpengaruh negatif terhadap penyaluran kredit melalui profitabiltias. Artinya, semakin tinggi risiko kredit bank umum di Indonesia maka akan semakin rendah penyaluran kredit bank umum di Indonesia melalui profitabilitas. Temuan ini memberikan gambaran bahwa manajemen bank umum di Indonesia harus mampu menjaga dan menurunkan kredit bermasalah agar dapat menghasilkan pendapatan yang maksimal dan mampu menyalurkan kredit ke masyarakat untuk menggenjot pertumbuhan ekonomi. Risiko kredit yang semakin tinggi akan menurunkan profitabilitas dari bank. 
Profitabilitas yang tergerus karena adanya kredit bermasalah akan mengakibatkan bank sulit untuk menyalurkan kredit kepada masyarakat. Dengan kata lain, dalam kurun waktu 2012 hingga 2016 bank menggunakan profitabilitas sebagai dasar dalam menyalurkan kredit kepada masyarakat dengan memperhatikan kredit bermasalah tersebut. Risiko kredit yang tinggi akan mengakibatkan hilangnya profitabilitas atau kemampuan bank dalam memperoleh laba mengingat hingga saat ini kredit merupakan salah satu sumber utama pendapatan dari bank. Ketika terdapat kredit yang bermasalah atau kredit macet maka pasti akan mengganggu tingkat profitabilitas dari bank tersebut dan membuat bank sulit untuk melakukan ekspansi kredit.

Hal ini mengindikasikan bahwa bank umum di Indonesia perlu melakukan inovasi untuk meraih keuntungan dan tidak hanya mengandalkan kredit sebagai sumber keuntungan utama. Menurut (Melania, Gusnardi, \& Indrawati, 2015) di tengah kondisi teknologi yang berkembang begitu pesat atau pada era digital saat ini, kebutuhan masyarakat akan jasa keuangan tidak lagi mengandalkan kredit sebagai earning assets. Bank perlu melakukan penguatan terhadap produkproduk yang dapat menghasilkan pendapatan non-bunga atau fee based income seperti pengelolaan rekening, bisnis kartu, transaksi ATM dan pendapatan bunga lainnya. Sehingga hal ini akan mengurangi ketergantungan bank dalam menghasilkan keuntungan melalui kredit tersebut.

\section{Kesimpulan dan Saran}

\section{Kesimpulan}

Penelitian ini bertujuan untuk menganalisis pengaruh risiko kredit terhadap profitabilitas bank umum di Indonesia, untuk menganalisis pengaruh risiko kredit terhadap penyaluran kredit bank umum di Indonesia, untuk menganalisis pengaruh profitabilitas terhadap penyaluran kredit bank umum di Indonesia, untuk menganalisis pengaruh risiko kredit terhadap penyaluran kredit bank umum di Indonesia melalui profitabilitas. Hasil penelitian menunjukkan bahwa risiko kredit berpengaruh negatif terhadap profitabilitas, risiko kredit tidak berpengaruh terhadap penyaluran kredit bank umum di Indonesia, profitabilitas berpengaruh positif terhadap penyaluran kredit bank umum di Indonesia dan risiko kredit berpengaruh negatif terhadap penyaluran kredit bank umum di Indonesia melalui profitabilitas.

Jadi, penyaluran kredit bank umum di Indonesia belum memenuhi target yang telah ditetapkan oleh Bank Indonesia bersama dengan pemerintah untuk mampu meningkatkan pertumbuhan ekonomi dikarenakan bank umum di Indonesia masih menghadapi tantangan dimana tingkat risiko kredit dalam kurun waktu 2012 hingga 2016 terus mengalami peningkatan yang mengakibatkan profitabilitas menurun dan menyulitkan bank menyalurkan kreditnya kepada masyarakat.

\section{Saran}

Penyaluran kredit kepada masyarakat merupakan salah satu cara agar pertumbuhan ekonomi meningkat. Peranan bank sebagai lembaga intermediasi sangat dibutuhkan untuk menggerakan roda perekonomian yang ada di tengah-tengah masyarakat. Dalam hal ini, kredit yang hendak disalurkan kepada masyarakat harus ditingkatkan kualitasnya.

Dalam rangka memberikan kualitas kredit yang baik maka hendaknya bank melakukan analisis yang mendalam dan melakukan penelitian kepada calon nasabah, setelah itu apabila 
telah disalurkan maka bank perlu terus memantau, menjaga dan memberikan arahan kepada nasabah agar nasabah mampu membayar kewajibannya sebelum jatuh tempo. Hal ini penting dilakukan, agar nasabah merasa aman dan nyaman dalam melakukan transaksi dengan bank. Pendampingan, pemantauan, penilaian dan pengikatan akan jaminan dapat memperkecil risiko kredit yang dihadapi oleh bank.

Bagi penelitian selanjutnya agar menambahkan variabel-variabel internal perbankan seperti CAR, LDR dan BOPO serta dapat menambahkan faktor makro ekonomi seperti inflasi, SBI, dan tingkat bunga. 


\section{Daftar Pustaka}

Amelia, K. C., \& Murtiasih, S. (2017). Analisis Pengaruh DPK,LDR,NPL dan CAR Terhadap Jumlah Penyaluran Kredit Pada PT.Bank QNB Indonesia, Tbk Periode 2005-2014. Jurnal Ekonomi Bisnis, 22(1), 66-74.

Anggreni, M. R., \& Suardhika, I. M. S. (2014). Pengaruh Dana Pihak Ketiga, Kecukupan Modal, Risiko Kredit dan Suku Bunga Kredit Pada Profitabilitas. E-Jurnal Akuntansi Universitas Udayana, 9(1), 27-38.

BI. (2016). Laporan Perekonomian Indonesia 2016 (pp. 102). Jakarta: Bank Indonesia.

Haryanto, S. B., \& Widyarti, E. T. (2017). Analisis Pengaruh NIM,NPL,BOPO,BI RATE, dan CAR Terhadap Penyaluran Kredit Bank Umum Go Public Periode Tahun 2012-2016. Diponegoro Journal Of Management, 6(4), 1-11.

Li, F., \& Zou, Y. (2014). The Impact of Credit Risk Management on Profitabilty of Commercial Banks: A Study of Europe. (Master), Umea University, Umea.

Mahardian, P. (2008). Analisis Pengaruh Rasio CAR,BOPO,NPL,NIM dan LDR Terhadap Kinerja Keuangan Perbankan. (Master), Univrsitas Diponegoro, Semarang.

Melania, L., Gusnardi, \& Indrawati, H. (2015). Pengaruh Risiko Kredit Terhadap Tingkat Profitabilitas Pada Bank Umum Go Public Tahun 2014. Jurnal Ekonomi Keuangan, 1(1), $1-10$.

Mukhlis, I. (2011). Penyaluran Kredit Bank Ditinjau Dari Jumlah Dana Pihak Ketiga Dan Tingkat Non Performing Loans. Jurnal Keuangan dan Perbankan, 15(1), 130-138.

Pratama, B. A. (2010). Analisis Faktor-Faktor Yang Mempengaruhi Kebijakan Penyaluran Kredit Perbankan. (Pascasarjana), Universitas Diponegoro, Semarang.

Pratiwi, S., \& Hindasah, L. (2014). Pengaruh Dana Pihak Ketiga, Capital Adequacy Ratio, Return on Asset, Net Interest Margin, dan Non Performing Loan Terhadap Penyaluran Kredit Bank Umum di Indonesia. Jurnal Manajemen \& Bisnis, 5(2), 192-208.

Puspitasari, D. (2009). Analisis Pengaruh CAR,NPL,PDN,NIM,BOPO,LDR, Dan Suku Bunga SBI Terhadap ROA. (Master), Univeersitas Diponegoro, Semarang.

Putri, W. O. P., \& Suwarti, T. (2013). Penyaluran Jumlah Kredit Perbankan dan Fakor Yang Mempengaruhinya. Jurnal Manajemen \& Bisnis, 2(2), 1-6.

Saroinsong, A. N. (2014). Fungsi Bank Dalam Sistem Penyaluran Kredit Perbankan. Jurnal Lex Privatum, 2(3), 130-137.

Septiani, R., \& Lestari, P. V. (2016). Pengaruh NPL Dan LDR Terhadap Profitabilitas Dengan CAR Sebagai Variabel Mediasi Pada PT BPR Pasaraya Kuta E-Jurnal Manajemen Universitas Udayana, 5(1), 293-324.

Widokartiko, B., Achsani, N. A., \& Beik, I. S. (2016). Dampak Kinerja Internal Dan Kondisi Makro Ekonomi Terhadap Profitabilitas Pada Perbankan Jurnal Aplikasi Bisnis dan Manajemen, 2(2), 161-171. doi: 10.17358/JABM.2.2.161

Yuliana, A. (2014). Pengaruh LDR,CAR,ROA, dan NPL Terhadap Penyaluran Kredit Pada Bank Umum di Indonesia Periode 2008-2013. Jurnal Dinamika Manajemen, 2(3), 169-186. 
Vol. 2 No. 2 September 2021

Riset Ekonomi. Alkuntansi dan Perpajakan e-ISSN : 2721-4109

DOI:10.30812/rekan.v2i2.1504 